\title{
The Effectiveness of Audio Visual Media Intervention Aku Bangga Aku Tahu (ABAT) toward Adolescent Attitude as a Practice of Prevention of HIV and AIDS Transmission
}

\author{
Nuramalia; Ida Leida Maria ${ }^{1}$; Nurhaedar Jafar ${ }^{2}$ \\ ${ }^{1}$ Department of Epidemiology, Faculty of Public Health, Hasanuddin University, Indonesia \\ ${ }^{2}$ Nutrition Department, Faculty of Public Health, Hasanuddin University, Indonesia
}

http://dx.doi.org/10.18415/ijmmu.v6i5.1177

\begin{abstract}
Learning media have an important role in supporting the delivery of information, one of the learning media that is currently developing is audio visual media. Recognizing the problems faced in efforts to prevent and control HIV and AIDS among adolescent groups, then through audio-visual media, I am Proud I Know (ABAT) as an education to spread true and comprehensive knowledge about HIV and AIDS. This study aims to determine the effect of ABAT audio-visual media on attitudes about HIV and AIDS at school adolescents in Makassar City. The research design uses quasy experiment with The Nonequivalent Control Group Design. The sampling technique used was simple random sampling, as many as 96 adolescents. The results showed that most respondents were in the age group of 17 years (49\%), female sex (52\%), grade 12 level (51\%). Based on the results of the Mann-Whitney U Test, there were differences in attitude before and after the intervention of ABAT audio-visual media playback with a frequency of playback three times and once in the intervention group and the control group $(p=0.036)$. Conclusion: there are significant differences in adolescent attitudes about HIV and AIDS before and after the intervention. Some comparison of counseling media is needed in order to better know the effectiveness of a media.
\end{abstract}

Keywords: Audio Visual Media; Aku Bangga Aku Tahu; HIV and AIDS; Attitude

\section{Introduction}

HIV or Human Immunodeficiency Virus is a type of virus that attacks white blood cells so it causes the human immune system to decline (Nowak \& McMichael, 1995). AIDS or Acquired Immune Deficiency Syndrome is a collection of symptoms that arise due to a decrease in a person's immune system due to being infected by HIV (Kemenkes,RI, 2018). In sub-Saharan Africa, the percentage of adolescents (15-24 years) who show a comprehensive and accurate understanding of HIV is low (36\% for young men and $28 \%$ for young women) (UNAIDS, 2013). 
In Indonesia, HIV and AIDS were first discovered in the province of Bali in 1987. Until now HIV and AIDS has spread to 386 districts / cities in all provinces in Indonesia. The highest percentage of HIV infections reported (Kemenkes,RI, 2018) according to age group in 2017 is 25-49 years old (69.2\%), 2024 years $(16.7 \%), \geq 50$ years $(7.6 \%), 15-19$ years $(4.0 \%), \leq 4$ years $(1.8)$. The age group of $15-19$ years experiences an increase in the number of cases of HIV infection.

The situation of HIV cases in Makassar city according to age group in 2018, the number of HIV in the age group (<4-14 years) is 9 cases, (15-19 years) as many as 17 cases, (20-24 years) as many as 104 cases, (25-49 years) as many as 503 cases and (> 50 years) as many as 25 cases of HIV infection (KPAP Sulawesi Selatan, 2017). The higher the percentage of sexually active teens, the higher the risk they face, including from sexually transmitted diseases and pregnancy. Therefore, protective measures need to be taken to prevent it (Etrawati, Martha, \& Damayanti, 2017).

Good knowledge will be realized with a good attitude, the formation of a negative attitude if the knowledge is not good. Because attitude is the readiness to react to certain environmental objects (Notoatmodjo, 2012). One phase that has a high vulnerability to HIV and AIDS transmission is adolescence. Adolescence is a combination of the psychological and biological age of development that becomes multifactorial in society (Pratiwi \& Hari Basuki, 2011).

\section{Methods}

This type of research is quantitative research using quasy experimental design with the design of The Nonequivalent Control Group Design. Three measurements were made, once before the intervention and twice after the intervention. This research was conducted in four schools, namely SMAN 3, SMAN 12, Bajiminasa SMAS, and YP PGRI 2 SMART Makassar City.

The population in this study were all students of grade 11, and 12 in SMAN 12, SMAN 3, Bajiminasa and YP PGRI 2 Makassar City and were willing to participate in the study by signing informed consent. The sampling technique used is simple random sampling. Samples totaled 96 people.

Data collection was carried out three times using a questionnaire. Starting with the first pre-test, then ABAT audio-visual media intervention was carried out. After the intervention, the first post test is given at a distance of two weeks after the intervention. Two weeks later, a second post test was given. The ABAT audio visual media intervention consisted of three sessions over one week for the intervention group. The control group was given one session a week. Each meeting session discussed about reproductive health, drugs, lifestyle, HIV and AIDS provided by the facilitator for 120 minutes each session and in the research process. Data were analyzed using SPSS using paired t test if the data were normally distributed and Wilcoxon test if the data were not normally distributed. 


\section{Results and Discussion}

Tabel 1 Distribution of Respondents Based on Characteristics in the Intervention and Control Group in Makassar City in 2019

\begin{tabular}{|c|c|c|c|c|c|c|}
\hline \multirow{3}{*}{ Characteristics } & \multicolumn{4}{|c|}{ School Teenagers } & \multirow{2}{*}{\multicolumn{2}{|c|}{ Total }} \\
\hline & \multicolumn{2}{|c|}{ Intervention } & \multicolumn{2}{|c|}{ Control } & & \\
\hline & $\mathrm{n}(48)$ & $\%$ & $\mathrm{n}(48)$ & $\%$ & $\mathrm{n}(96)$ & $\%$ \\
\hline \multicolumn{7}{|l|}{ Age } \\
\hline 16 year & 22 & 45,8 & 24 & 50 & 46 & 48 \\
\hline 17 year & 25 & 52,0 & 22 & 45,8 & 47 & 49 \\
\hline 18 year & 1 & 2,0 & 2 & 4,16 & 3 & 3,1 \\
\hline \multicolumn{7}{|l|}{ Gender } \\
\hline Men & 25 & 52,0 & 21 & 43,7 & 46 & 48 \\
\hline Women & 23 & 47,9 & 27 & 56,2 & 50 & 52 \\
\hline \multicolumn{7}{|l|}{ Class } \\
\hline 11 & 19 & 39,5 & 28 & 58,3 & 47 & 48,9 \\
\hline 12 & 29 & 60,4 & 20 & 41,6 & 49 & 51,0 \\
\hline \multicolumn{7}{|l|}{ Majors } \\
\hline IPA & 38 & 79,1 & 45 & 93,7 & 83 & 86,4 \\
\hline IPS & 10 & 20,8 & 3 & 6,2 & 13 & 13,5 \\
\hline
\end{tabular}

The results of the study describe the characteristics of respondents consisting of age, gender, grade level and majors. In table 1 the characteristics of respondents by age in the intervention and control groups were at most age 17 years at 49\% (47 people). Most were female (52\%) with grade $12(51 \%)$ and from the science major $(86.4 \%)$.

Tabel 2 Distribution of Respondents Attitude Categories Before and After ABAT Interventions in Makassar City in 2019

\begin{tabular}{lcccc}
\hline \multirow{2}{*}{ Attitude Category } & \multicolumn{5}{c}{ School Teenagers } \\
\cline { 2 - 5 } & \multicolumn{2}{c}{ Intervention } & \multicolumn{2}{c}{ Control } \\
\cline { 2 - 5 } & $\mathrm{n}$ & $\%$ & $\mathrm{n}$ & $\%$ \\
\hline Pre Test & 28 & 58,3 & 3 & 6,25 \\
Negative $(\leq 32,5)$ & 20 & 41,6 & 45 & 93,7 \\
Positive $(>32,5)$ & 0 & 0 & 0 & 0 \\
\hline Post Test 1 & 48 & 100 & 48 & 100 \\
Negative $(\leq 32,5)$ & & & & \\
Positive $(>32,5)$ & 0 & 0 & 0 & 0 \\
Post Test 2 & 48 & 100 & 48 & 100 \\
Negative $(\leq 32,5)$ & & & & \\
Positive $(>32,5)$ & &
\end{tabular}


Table 2 shows that the category of respondents' attitudes in the intervention group prior to the intervention in the pre-test was in the negative attitude category of $58.3 \%$ (28 people) while the positive attitude category was $41.6 \%$ (20 people). After the ABAT audio visual media intervention, both post-test 1 and post-test 2 experienced an overall increase into a positive category. In the control group before the intervention in the pre-test also the most was in the positive category of $93.7 \%$ (45 people) while the negative category was $6.25 \%$ ( 3 people). After the intervention, both post-test 1 and post-test 2 also increased overall to a positive category.

Tabel 3 Distribution of Differences in Respondent Attitude Before and After ABAT Interventions Three Times in Makassar City in 2019

\begin{tabular}{cccccc}
\hline Test group & Attitude & Min & Max & Mean \pm SD & Nilai $p$ \\
\hline Pre-Post 1 & Pre & 26 & 49 & $32,81 \pm 5,043$ & $<0,000$ \\
$($ O1 - O2 $)$ & Post 1 & 33 & 50 & $38,69 \pm 5,011$ & \\
\hline Post 1 Post 2 & Post 1 & 33 & 50 & $38,69 \pm 5,011$ & \\
$\left(O_{2}-\mathrm{O}_{3}\right)$ & Post 2 & 33 & 52 & $40,31 \pm 3,821$ & 0,064 \\
\hline Pre Post 2 & Pre & 26 & 49 & $32,81 \pm 5,043$ & \\
$\left(\mathrm{O}_{1}-\mathrm{O}_{3}\right)$ & Post 2 & 33 & 52 & $40,31 \pm 3,821$ & $<0,000$ \\
\hline
\end{tabular}

In table 3 it can be said that there was an increase in the average attitudes of school adolescents before and after being given the audio visual ABAT intervention. This increase was seen from the average pre-test score of 32.81 which then increased to 38.69 at the time of the post-test I. The average difference in the pre-test and post-test scores was 5.88. Wilcoxon test results obtained a significance value of 0,000 ( $\mathrm{p}<0.05)$, thus there are differences in the attitudes of respondents before and after ABAT intervention in the intervention group.

Tabel 4 Distribution of Differences in Respondent Attitude Before and After ABAT Interventions, One Time in Makassar City in 2019

\begin{tabular}{cccccc}
\hline Test group & Attitude & Min & Max & Mean \pm SD & Nilai $p$ \\
\hline Pre-Post 1 & Pre & 30 & 49 & $41,94 \pm 4,935$ & $<0,016$ \\
$($ O1 - O2) & Post 1 & 33 & 51 & $43,83 \pm 4,018$ & \\
\hline Post 1 Post 2 & Post 1 & 33 & 51 & $43,83 \pm 4,018$ & \\
$\left(O_{2}-\mathrm{O}_{3}\right)$ & Post 2 & 37 & 52 & $43,96 \pm 2,813$ & \\
\hline Pre Post 2 & Pre & 30 & 49 & $41,94 \pm 4,935$ & \\
$\left(\mathbf{O}_{1}-\mathbf{O}_{3}\right)$ & Post 2 & 37 & 52 & $43,96 \pm 2,813$ & $<0,000$ \\
\hline
\end{tabular}


In table 4 the distribution of differences in attitudes in the control group, it can be said that an increase in the average score of school adolescent attitudes before and after getting the intervention. This increase was seen from the average pre-test score of 41.94 to 43.83 in the post-test 1 . The results of paired $\mathrm{t}$-test were obtained $\mathrm{p}$ value of $0.016<0.05$. So it was concluded that there were significant differences in the attitudes of respondents before and after the ABAT intervention.

Tabel 5 Differences in Respondent Knowledge After ABAT Intervention Three Times and One Time in Makassar City in 2019

\begin{tabular}{lccc}
\hline \multirow{2}{*}{ Attitude } & \multicolumn{2}{c}{ School Teenagers } & \multirow{2}{*}{ * $^{*}$ value } \\
\cline { 2 - 3 } & Post Test 1 & Post Test 2 & \\
\hline Intervention & 14 & 12 & 0,953 \\
Min & 24 & 24 & \\
Max & 21,50 & 21,27 & \\
Mean & $\pm 2,124$ & $\pm 2,615$ & 0,897 \\
Standard Deviation & & & \\
Control & 10 & 12 & \\
Min & 24 & 24 & \\
Max & 19,52 & 19,54 & \\
Mean & $\pm 3,003$ & $\pm 3,149$ & \\
Standard Deviation & & & \\
& 0,000 & 0,001 & \\
$p^{* *}$ value & & & \\
\end{tabular}

Tabel 5 menunjukkan hasil uji statistik menggunakan Mann-Whitney U Test maka diperoleh nilai $p<0,05$ pada post-test 1 dan post-test 2 . Hal ini menunjukkan bahwa ada perbedaan secara bermakna pada sikap antara kelompok intervensi dan kelompok kontrol setelah diberikan intervensi. Sedangkan hasil uji Wilcoxon pada pada post-test 2 diperoleh nilai significancy sebesar $(0,064>0,05)$ yang menunjukkan bahwa ada tidak ada perbedaan sikap pada post-test 2 untuk kelompok intervensi. Meskipun secara statistik tidak terdapat perbedaan namun terjadi peningkatan nilai min dan max pada pos-test 2 kelompok intervensi. Hal ini juga menunjukkan bahwa sikap remaja bertahan dengan baik dengan jarak pengukuran selama 2 minggu dari post-test 1. Untuk kelompok kontrol diperoleh nilai $p$ $(0,000<0,005)$ maka dapat ditarik kesimpulan bahwa terdapat perbedaan secara bermakna pada sikap kelompok kontrol pada post-test 2 .

The average age of respondents in both groups was 17 years (48.9\%) so that it is classified as late adolescents. Based on psychosocial and sexual maturity all adolescents will go through three stages, namely early / early adolescence (Early adolescence 11-13 years), middle adolescence (Middle adolescence 14-16 years), late adolescence (Late adolescence 17-20) (Soetjiningsih, 2004).

The majority of sexes in this study were women (52\%) more than the male sex (48\%), this tendency occurred because the number of female student council administrators was more than men. This study is in line with (Rahayu, Rismawanti, Jaelani, \& Indragiri, 2017) which states that there are more female respondents in each class compared to the number of male respondents. Then the sample chosen is dominated by women.

Attitude is a readiness to react to certain environmental objects as an appreciation of objects (Notoatmodjo, 2012b). Often in the discussion of adolescent questions the terms puberty and adolescent 
are used. The term puberty is used to express biological changes, especially reproductive capacity, namely changes in genitals from the child to adult stage (Soetjiningsih, 2004).

The results of the bivariate analysis showed that there were differences in attitudes about HIV and AIDS between the intervention and control groups. The results obtained with the value $(\mathrm{p}<0.05)$ mean that ABAT audiovisual media has a significant influence on the improvement of adolescent attitudes towards HIV and AIDS. This study is in line with research conducted by (Natalia et al., 2015) that information services using audio visual media can improve students' attitudes towards school discipline. This effectiveness can be seen from the total score of the intervention group experiencing a significant increase.

Based on the results of data analysis, it shows that the attitude towards the practice of HIV and AIDS prevention after being given the audiovisual media intervention of ABAT is in the good category. A good attitude of respondents towards HIV and AIDS prevention efforts will have an impact on respondents' actions in preventing HIV and AIDS, this is in accordance with the theory put forward by (Azwar, 2016) that health behavior can be influenced by one's attitude because attitude is a hidden behavior so someone's actions will be in line with his attitude. Changes in attitude are also influenced by the length of time someone remembers a message. In accordance with Brigham's opinion, with the concept of sleeper effect which states that people may still remember the contents of the message delivered within 10-14 days after the message was delivered.

According to Riyana in research (Ifroh \& Ayubi, 2018) that the purpose of learning by using audio-visual media is to clarify and facilitate communicators to convey health messages so that the information conveyed is not too verbalistic. Audiovisual media can also overcome the limitations of time, distance, and the senses of students and communicators, and audiovisual media can be used appropriately and varied.

\section{Conclusion}

The effectiveness of the ABAT audio visual media on a meaningful attitude there are differences in attitudes about HIV and AIDS before and after being given intervention three times and once. Based on the results of this study, there are still aspects of attitudes in adolescents that need to be improved such as being more open with parents.

\section{References}

Azwar, S. (2016). Sikap Manusia Teori dan Pengukurannya. Yogyakarta: Pustaka Pelajar.

Etrawati, F., Martha, E., \& Damayanti, R. (2017). Psychosocial Determinants of Risky Sexual Behavior among Senior High School Students in Merauke District. Kesmas: National Public Health Journal, 11(3), 127-132. https://doi.org/10.21109/kesmas.v11i3.1163.

Ifroh, R. H., \& Ayubi, D. (2018). Efektivitas Kombinasi Media Audiovisual Aku Bangga Aku Tahu Dan Diskusi Kelompok Dalam Upaya Meningkatkan Pengetahuan Remaja Tentang HIV-AIDS. Perilaku dan Promosi Kesehatan, 1(1), 32-43. 
Kemenkes RI. (2018). Laporan HIV AIDS TW 4 Tahun 2017.

KPAP Sulawesi Selatan. Sosialisasi Pencegahan Dan Penanggulangan Hiv \& Aids Di Lingkungan Tempat Kerja (2017).

Natalia, N., Firman, \& Daharnis. (2015). Efektivitas Layanan Informasi dengan Menggunakan Media Audio Visual dalam Jurnal Konseling dan Pendidikan, (October 2018).

Notoatmodjo. (2012a). Metodologi Penelitian Kesehatan. Jakarta: Rineka Cipta.

Notoatmodjo. (2012b). Promosi Kesehatan Dan Ilmu Perilaku. Jakarta: Rineka Cipta.

Nowak, M. A., \& McMichael, A. J. (1995). How HIV defeats the immune system. Scientific American, $273(2), 58-65$.

Rahayu, I., Rismawanti, V., Jaelani, A. K., \& Indragiri, A. K. (2017). Hubungan Tingkat Pengetahuan Tentang HIV dan AIDS dengan Perilaku Seksual Pranikah Pelajar, 2(June), 145-150.

Soetjiningsih. (2004). Tumbuh Kembang Remaja Dan Permasalahannya. Jakarta: CV. SAGUNG SETO. UNAIDS. (2013). GLOBAL REPORT: UNAIDS report on the global AIDS epidemic 2013. Unaids. https://doi.org/JC2502/1/E.

\section{Copyrights}

Copyright for this article is retained by the author(s), with first publication rights granted to the journal.

This is an open-access article distributed under the terms and conditions of the Creative Commons Attribution license (http://creativecommons.org/licenses/by/4.0/). 